\title{
5. The gilded cage: Rhetorical path dependency in Australian politics
}

\author{
Dennis Grube
}

Every writer at the start of a new project is confronted by something that is at once terrifying and liberating - a blank piece of paper. They are given a clean slate on which to shape and build a story full of rich characters and events that respond to each push of the writer's pen. In politics, rhetorical actors seldom enjoy the luxury of a clean piece of paper. Each speech act does not stand alone as a fresh start, but is rather the next in a long line of speeches, media statements and framing narratives that have helped to define a political actor in the public mind over time. Every time a political leader speaks, they do so dragging behind them the collected rhetorical baggage of a lifetime in politics. In the process of accumulating this baggage, they have had to make rhetorical choices at each point that have narrowed the range of rhetorical options open to them for the future. To suddenly depart from established lines of rhetoric that have shaped a politician's image leaves them exposed to looking inauthentic, inconsistent and untrustworthy - an array of attributes that can spell death in contemporary politics.

This chapter examines the idea of path dependency, a well-established concept in the field of policy studies, and applies it to the study of political rhetoric. I argue that political leaders are caught between the desire to utilise fresh and engaging rhetoric in order to better explain a new policy direction and the reality that they can't be seen to be contradicting themselves. They are effectively hemmed in by their own rhetorical choices, leaving them unable to easily start afresh in new rhetorical directions. They are trapped in a gilded rhetorical cage of their own making. To prosecute this argument, I draw on three recent case studies in which Australian political leaders have found themselves restrained by their own previous rhetorical choices, preventing them from effectively explaining changes in policy direction.

Kevin Rudd, on assuming the Labor leadership in 2006, argued consistently that climate change was the 'greatest moral challenge of our time', which required determined leadership in order to address it. The desire to formulate new rhetoric in 2010 to explain why immediate action had to be postponed was thwarted by rhetorical baggage of his own creation. During the 2010 election campaign, Prime Minister Julia Gillard insisted that there would be 'no carbon tax under the government I lead'. When confronted with the reality of a minority parliament and the demands of the Greens for climate action, the 
prime minister fought a losing rhetorical battle to differentiate the new policy realities from her previous political rhetoric. Tony Abbott, as Opposition leader, presented a consistent rhetorical refrain that the boats of asylum seekers had to be stopped, and turned around on the high seas where it was safe to do so. Upon attaining office as prime minister in September 2013, Abbott faced the task of reshaping his political rhetoric to avoid conflict with the Indonesian Government without looking like he was deviating from his earlier rhetorical position. Before examining each of these three cases in detail, I turn first to the concept of path dependency.

\section{Path dependency and political rhetoric}

Path dependency is an idea that emerged from theories of historical institutionalism. In essence, path dependency argues that no actor is capable of escaping easily from her or his own history. 'Path dependency speaks to the common observation that the legacy of the past conditions our future, at the policy level and at the level of institutions' (Gains et al. 2005: 27). Path dependency applies not just to individual actors, but to bureaucratic departments, policy processes and programs.

Whenever a political actor or an institution adopts a particular policy position, processes are put in place to allow that policy to be implemented. A new agency might be set up, staff recruited and headquarters built. Legislation might be passed. Money will be spent rolling out the policy in whichever way is appropriate. These types of sunk costs mean that a complete change in policy direction becomes increasingly difficult. In fact, not only do the costs of change become prohibitive, but there are 'increasing returns' that will flow to those who stay on the path originally selected. As one of the first theorists to explain the applicability of path dependency to questions of political science, Paul Pierson explains it this way:

Increasing returns dynamics capture two key elements central to most analysts' intuitive sense of path dependence. First, they pinpoint how the costs of switching from one alternative to another will, in certain social contexts, increase markedly over time. Second, and related, they draw attention to issues of timing and sequence, distinguishing formative moments or conjunctures from the periods that reinforce divergent paths. In an increasing returns process, it is not only a question of what happens but also of when it happens. Issues of temporality are at the heart of the analysis. (2000: 251) 
Such path dependent effects are seen clearly in policy development processes:

In terms of policy development, path dependency captures the tendency for a policy step in one direction to encourage the next step to be in a similar direction. Fundamentally, the set up of the policy conditions later choices. A period of instability leads to a policy being defined and once defined the development of policy tends to follow the underlying assumptions, sense of direction and the coalition of interests that accompanied its launch. The key theoretical insight to emerge from the path dependency literature is that increasing returns experienced by the actors involved keeps them along the same path. (Gains et al. 2005: 27)

A recent Australian example illustrates such effects well. Instigated under the Rudd government, the National Broadband Network (NBN) project saw the establishment of a new government-owned corporation - NBN Co - and the spending of billions of dollars to begin the roll out of fibre to the home across Australia. The Coalition, under the leadership of then Opposition leader Abbott, made clear that it did not support the NBN project in its current form. But in laying out its own plan in the lead up to the 2013 election, the Abbott-led Coalition did not have a clean policy slate on which to draw. In theory, they could have promised to rip up every piece of cabling already laid to individual homes in various parts of Australia, abolished NBN Co and begun a new tendering process for an alternative model of high-speed broadband delivery. In practice, the costs of such an option are simply too high in both financial and policy terms. Too much money has been spent, and too many processes established, to simply start again in an entirely new direction. The stated policy of the Coalition government involves some change in direction going forward, but the point of departure from the policy of the previous government is already well down a path that they cannot and will not seek to reverse in its entirety.

I argue here that this type of path dependency is just as applicable to the rhetoric of political leaders as it is to policy outcomes. Political 'talk' is important in part because it helps to shape our views of the person doing the talking. The rhetoric of political leaders contributes to the shaping of the public's perception of them. It helps to frame their political persona. The more often they repeat particular rhetorical choices and stick to a particular formulation, the more it becomes entrenched as part of their public face. This can bring significant rewards for leaders who are able to then live up to that rhetoric by delivering on what they have promised. But equally it can leave them little room for rhetorical readjustment when things change. As leaders are reminded every day, politics is difficult. Public opinion can shift, government finances can change, and what seemed like a wonderfully clear piece of persuasive rhetoric can become, instead, a millstone around a political leader's neck. 
The incentives for leaders to adapt and change their rhetoric are, therefore, high because the complexities and nuances of political reality require leaders to have room to move and opportunities to change position. But perversely, the more 'successful' leaders have been in their political rhetoric, the less room for manoeuvre they leave themselves. Political rhetoric has a narrowing effect as leaders are pushed towards clear, unequivocal statements that they can then be held to. The result is that rhetorical refrains become ever more deeply etched in political concrete and the costs for leaders of starting afresh in a new rhetorical direction become prohibitive.

But our political leaders have little choice other than to take some rhetorical risks and state a position. They cannot simply refuse to say anything and commit to nothing and still hope to govern effectively. Having decided on a form of words that they believe will be persuasive in carrying their policy narrative to the wider public, political leaders receive the increasing returns of being seen to be consistent and committed to the path they have identified. But if a political leader changes rhetorical direction, no amount of further consistent rhetoric is sufficient to offset the cost of the initial change. For example, having embraced a price on carbon, Prime Minister Gillard explained its virtues consistently for over two years, but was unable to overcome the weight of the initial rhetorical commitment not to introduce a carbon tax.

As Pierson's analysis of path dependency indicates, at the outset a leader is faced with an array of possible rhetorical formulations for carrying a policy message. But, having once selected a particular formulation, it immediately raises the political cost of then adopting an alternative.

In an increasing returns process, the probability of further steps along the same path increases with each move down that path. This is because the relative benefits of the current activity compared with other possible options increase over time. To put it a different way, the costs of exit of switching to some previously plausible alternative — rise. (Pierson 2000: 252)

For example, Ryan Walter's chapter in this book on the language of economic management examines how the Gillard government painted itself into a rhetorical corner by repeatedly promising to deliver a surplus in 2013. It passed up many early opportunities to reshape or reframe the promise and, instead, entrenched it further by repetition and insistent commitment. At each point, the costs of adopting different rhetoric increased, making anything other than strong repetition of the commitment untenable. Of course, as Walter explains, the contingent nature of political reality finally caught up with the rhetoric. 
The resultant political pain of the rhetorical shift away from promising the surplus was commensurate with the distance the government had gone down that particular rhetorical path.

So, once adopted at the outset, a particular rhetorical formulation will naturally enough become further entrenched through repetition and further explication. But there is also a small temporal window for clarification, in which a rhetorical misstep can be reversed without the same level of cost that will apply if the original misstep is expanded on and entrenched. For example, in $2010 \mathrm{Abbott}$ was forced in an interview on the 7.30 program to backtrack on a commitment he had made not to increase any taxes under a Coalition government. He committed himself to a policy direction that he had not intended and tried immediately to withdraw the comment:

I know politicians are going to be judged on everything they say, but sometimes in the heat of discussion you go a little bit further than you would if it was an absolutely calm, considered, prepared, scripted remark. Which is one of the reasons why the statements that need to be taken absolutely as gospel truth are those carefully prepared, scripted remarks. (Australian Broadcasting Corporation (ABC) 2010)

Abbott's 'clarification' about the policy position on tax, whilst attracting criticism and even ridicule for the manner of his clarification, enabled him to stop a particular piece of policy rhetoric from becoming embedded. It cost him some political capital to deviate immediately from a rhetorical formulation, but it also enabled him to stop it from growing into a more path dependent rhetorical formulation that he would then become 'stuck' with.

I turn now to an in-depth discussion of three recent Australian cases that highlight the effects of rhetorical path dependency at work.

\section{Kevin Rudd and climate change}

For much of the first decade of the twenty-first century, Australia was experiencing severe drought conditions across multiple states. Amongst concerns over dramatically reduced water flows in the Murray-Darling Basin, failing farms and the drying up of urban water reservoirs, the climate change debate seemed grounded in real, practical and visible environmental consequences. Under Prime Minister John Howard, long considered something of a climate change sceptic, the push for action became irresistible. He flexed the Commonwealth's financial muscle to assert some control over the MurrayDarling Basin and, by 2007, he and his ministers were openly discussing options for a market-based mechanism to put a price on carbon. 
Part of the pressure for action was being built by the Australian Labor Party under the leadership of Rudd, who had replaced Kim Beazley in late 2006. Rudd promised that if Labor won government, one of its first acts would be to sign the Kyoto Protocol - the international agreement pledging action to control the rates of carbon entering the atmosphere. In an October 2006 piece in the The Monthly magazine, Rudd suggested action on climate change was an ethical duty for people of faith:

By definition, the planet cannot speak for itself. Nor can the working peoples of the developing world effectively speak for themselves, although they are likely to be the first victims of the environmental degradation brought about by climate change. Nor can those who come after us, although they are likely to be the greatest victims of this intergenerational injustice. It is the fundamental ethical challenge of our age to protect the planet - in the language of the Bible, to be proper stewards of creation. The scientific evidence is now clear, and the time for global, national and local action has well and truly come. (Rudd 2006)

When Labor gained government in November 2007, the Kyoto Protocol was indeed signed as the first official act of the new government.

Rudd continued to build his rhetoric throughout 2008 and 2009, ramping up the need for action. In July 2008, the draft report of the Garnaut Climate Change Review was released. The Prime Minister used the report to again stress the central importance of the issue:

And that is why the stark warnings contained in Professor Garnaut's report about the cost of inaction should focus our entire national debate on what we do on climate change. The bottom line is this, if we fail to act on climate change we are condemning great river systems like the Murray Darling to an entirely perilous future and the resolve of our Government is to act. It will be tough, it will be difficult, it will be expensive. But we intend to take on this challenge and to do our absolute best in responding to what I think is the great challenge of our generation. (Rudd 2008)

In the lead up to the December 2009 Copenhagen conference to tackle climate change, Rudd continued down his established rhetorical path of advocating the absolute necessity of action and the cowardice of inaction. Internationally, the Copenhagen summit failed to usher in a comprehensive agreement, and domestically Abbott had replaced Malcolm Turnbull as leader of the Liberal Party, bringing with him a sceptical view of the need for Rudd's proposed 
climate change policy solutions. What had been a bipartisan policy area suddenly became a heavily contested one, tying Rudd ever more publicly into rhetorical support for the importance of acting on climate change.

Having failed multiple times to convince the Greens in the Senate to support an emissions trading scheme incorporating modest emission reduction targets, Rudd was faced with the choice of pursuing a double dissolution election on the issue or delaying action. He chose the latter. At a press conference on 27 April 2010, Rudd announced that the government would delay acting on a carbon pollution reduction scheme because of the Liberal Opposition's intransigence and the indecisiveness of the rest of the world. He was immediately challenged with multiple questions from journalists, citing his earlier rhetorical narrative on the central importance of climate change:

Journalist: A little while back you said that climate change is the greatest moral, economic and social challenge of our time. With this now being delayed, do you still believe that to be the case?

PM: Climate change remains a fundamental economic and environmental and moral challenge for all Australians, and for all peoples of the world. That just doesn't go away for the simple reason that it's not in the headlines. Therefore, the practical question is this. Our current actions delivered through until the end of the current Kyoto commitment period which finishes at the end of 2012 - the critical question then is what actions postdate 2012, and the decision that we've taken as a Government is that that provides the best opportunity to judge the actions by the rest of the international community before taking our decision about the implementation of a Carbon Pollution Reduction Scheme from that time on. (Rudd 2010)

The news media highlighted the policy shift with gusto. Paul Kelly, editor-atlarge for the Australian wrote: As retreats go, they come no bigger than Kevin Rudd's delaying of his once cherished emissions trading scheme - one of the most spectacular backdowns by a prime minister in decades' (2010). Lenore Taylor wrote in the Sydney Morning Herald that:

When the Coalition began insisting on a wait-and-see position, Rudd said it was 'absolute political cowardice ... an absolute failure of leadership'. It would be a 'failure of logic', because if every nation said it could not do anything until everyone else did, no one would ever do anything. Now he's adopted the same position himself. He was right the first time. (2010)

In the weeks and months that followed, Rudd was not able to successfully reframe his climate change policy in a way that could again be rhetorically persuasive. He had simply proceeded too far down the rhetorical path of the need for Australian 
leadership on the great moral challenge of the age to be able to adopt a new message. His message had become a path-dependent prisoner of its own initial success in framing the climate change problem and the need for action.

\section{Julia Gillard and the carbon 'tax' or 'price'}

Gillard became prime minister on 24 June 2010, assuming the position following an extraordinary 24 hours in which the Labor caucus committed to a dramatic leadership change. As the new prime minister, Gillard faced allegations in the media that she had been one of the key ministers who had helped to block Rudd's initial desire to push through an emissions trading scheme (Hartcher 2010). On 27 June 2010, she was interviewed on Channel 9 by Laurie Oakes, who quizzed her on the topic:

Oakes: Now, you've now been pinged, along with Wayne Swan, as responsible for the shelving of the emissions trading system, the decision that more than anything else shredded Kevin Rudd's credibility. Do you accept responsibility for that?

PM: I accept my fair share of ...

Oakes: ... Which sounds like the lion's share from the reports we've had of the discussion.

PM: Well, I accept my fair share of the responsibility for all of the decisions that happened when Kevin Rudd was prime minister. I accept my fair share for the good things and the bad things.

Oakes: But you did argue that the ETS should be dumped because it was hurting Labor politically. Is that true?

PM: Laurie, [I] was concerned that if you are going to do something as big to your economy as put a price on carbon, with the economic transformation that implies, with changing the way in which we live, you need a lasting and deep community consensus to do it and I don't believe we have that lasting and deep community consensus now. Now I believe we should have a price on carbon and I will be prepared to argue for a price on carbon, to lead so that we get to that lasting and deep community consensus, but we're not there yet ... . (Gillard 2010a)

The Prime Minister's stated view on the need to delay the pricing of carbon until community consensus could be reached was widely picked up and reported in the print media - further entrenching the rhetorical path chosen and increasing the political cost of any later change. The Australian reported 
the interview under the headline 'Gillard says she led push for delay on ETS' (Maiden 2010) and the Australian Financial Review (AFR) under the headline 'Seeking "community consensus" ahead of an ETS' (2010).

After implementing swift policy solutions on the issues of asylum seeker arrivals and the mining tax - issues on which Rudd was perceived as having underperformed - Gillard called a federal election for 21 August 2010. During the campaign, when pressed further on the carbon pricing issue during a television interview on Channel 10, the Prime Minister ruled out implementing a carbon tax:

There will be no carbon tax under the government I lead. What we will do is tackle the challenge of climate change. We have invested record amounts in solar and renewable technologies. I want to build the transmission lines that will bring back clean green energy into the national average is the grid. I also want to make sure that we have no more dirty coal-fired power stations and make sure we tried [sic] greener cars and word [sic] from greener buildings. I will deliver those things and the[n] lead a national debate to reach a consensus about putting a cap on carbon pollution. (Gillard 2010b)

Once again, the print media picked up and amplified the core message that there would be no carbon tax under a Gillard government. Headlines such as 'Gillard rules out imposing carbon tax' (Sydney Morning Herald 2010) emphasised the seemingly definitive nature of the Prime Minister's rhetoric on the matter. It is now a matter of historical record that the Australian election of 2010 produced the first hung parliament since World War II. Gillard and Abbott each spent the subsequent days attempting to woo the support of key independents in order to form government. In Gillard's case, this included signing an agreement with the Greens to lock in the support of the new Greens MP for Melbourne, Adam Bandt, in the lower house. One aspect of the deal was the formation of a multiparty committee to examine options for action on climate change that could be presented to cabinet.

In February 2011, Gillard announced that the government would seek to introduce a carbon price to tackle climate change. She held a press conference on 24 February 2011, flanked by the members of the multi-party committee:

Today, accompanied by the members of the Multi-Party Climate Change Committee and we're here together today because we're releasing a paper which describes a proposed carbon mechanism.

Now this proposed mechanism for pricing carbon is agreed by the Australian Government and by the Australian Greens. Mr Windsor and Mr Oakeshott, who have joined us and who are members of the Multi- 
Party Climate Change Committee, have agreed that this proposal should be released to be considered by the community and to demonstrate that progress is being made ... I do want to take a few moments to explain why I am so determined to price carbon. (Gillard 2011)

In answering questions from journalists, Gillard framed the policy change as being a necessary reflection of the parliament that the Australian people had voted for:

Journalist: Thank you very much, Prime Minister. Is this announcement today a breach of faith with the electorate, given that immediately prior to the election you ruled out a carbon price?

PM: This is the parliament the Australian people voted for. You're seeing it on display in front of you. This is the parliament Australians voted for, and we have to get on with the job of pricing carbon. (Gillard 2011)

The Opposition seized on the announcement as a broken promise and the battle of the rhetorical frames between seeing the 'carbon price' as an important national reform and seeing the 'carbon tax' as a broken promise was played out through the media in the days, weeks, months and years that followed. Gillard had effectively been caught in the net of her own clear rhetorical formulations about what she would and would not do. Her rhetoric was so clear and consistent that it did what it was intended to do, which was entrench her position in the public mind. Each repetition of it took her further along a rhetorical path as she enjoyed the increasing political returns that come with enunciating a clear position on an issue. Equally, however, it raised the stakes of any subsequent change in rhetoric having a major impact on perceptions of her authenticity and trustworthiness. The political pain Gillard experienced when she announced the government's intention to price carbon was the direct mirror image of the political gain she had enjoyed from entrenching a particular rhetorical position.

Reflecting on her prime ministership in September 2013, Gillard, writing for the Guardian newspaper online, acknowledged that the policy shift had exacted a heavy political toll as she lost the rhetorical battle:

I erred by not contesting the label 'tax' for the fixed price period of the emissions trading scheme I introduced. I feared the media would end up playing constant silly word games with me, trying to get me to say the word 'tax'. I wanted to be on the substance of the policy, not playing 'gotcha'. But I made the wrong choice and, politically, it hurt me terribly. (2013) 


\section{Tony Abbott and stopping the boats}

The issue of what to do with asylum seekers who attempt to reach Australia by boat has played a dominant role in Australian political debate for over a decade. In the 1970s and 1980s, a bipartisan consensus operated to avoid pitched partisan disagreements over the arrival of 'boat people' fleeing Asia's trouble spots and, in particular, the conflict in Vietnam. The consensus was challenged and broken in 2001, when Howard was successful in reframing the issue of asylum seekers from a humanitarian problem to a border security problem. Just before the beginning of the 2001 election campaign, allegations surfaced that asylum seekers had thrown their children overboard to make sure that their boats would be picked up and taken to Christmas Island by Australian authorities. This allegation was later proven to be false. Howard vowed during the campaign that he would 'stop the boats.' In his formal election launch speech, he struck upon the powerful rhetorical appeal that: 'we will decide who comes to this country and the circumstances in which they come' (2001). Reelected with an increased majority, Howard put in place a policy which came to be known as the 'Pacific Solution' to excise Australia's offshore islands from its migration zone, and for asylum seekers to be processed offshore.

It was against this background that Abbott, as Opposition leader from 2009-2013, vowed that he would once again 'stop the boats' if he was elected as prime minister. Following their election win in 2007, the Rudd government had dismantled the Pacific Solution suite of policies, while conflicts in Afghanistan, Sri Lanka and Iraq fed into a renewed wave of asylum seekers attempting to reach Australia by boat. Abbott argued that only a Coalition government could effectively stop the boats because only a Coalition government believed in it (see Wroe and Hall 2013). The phrase 'stop the boats' was underpinned by a set of specific policy proposals, including turning boats around where it was 'safe to do so'.

Abbott's rhetoric was tested by comments from various experts suggesting that turning boats around would be unworkable. Abbott's constant recommitment to this goal entrenched it further in a path dependent fashion. It generated suitably decisive sounding headlines such as "I'll turn back every boat", says Tony Abbott' (Kelly 2012) and 'No turning back on Abbott navy stance' (Peake 2012). When criticised, Abbott simply reinforced the point. For example, the Australian on 7 July 2012 carried criticisms of the policy from former chief of defence, Admiral Chris Barrie:

Mr Abbott said Admiral Barrie, who executed the policy under the Howard government, had been misrepresented and the navy could tow back asylum boats once again. 'Under the Coalition government, there will always be the option of turning boats around where it is safe to do 
so,' Mr Abbott said. 'The turn-back-the-boats option is what we need if we are going to discourage reckless behaviour by people-smugglers and their clients,' he said. (Wilson and Vasek 2012)

Abbott, Foreign Affairs Shadow Minister Julie Bishop and Immigration Shadow Minister Scott Morrison were questioned intensively by journalists as to whether the policy would need to take greater account of the concerns of the country from which many of the boats set sail - namely Indonesia. They maintained strongly that Australia did not need the permission of another country to protect its own borders (e.g. Hall 2013).

The suite of policies to help 'stop the boats' were entrenched further during the 2013 election campaign, with press releases promising to:

Implement a \$20 million program with the International Organisation for Migration to engage and enlist Indonesian villages to support people smuggling disruption, including a capped boat buy-back scheme that provides an incentive for owners of dangerous vessels to sell them to government officials, not people smugglers. (Abbott 2013a)

The Coalition parties decisively won the 2013 election, and Abbott vowed that Operation Sovereign Borders would begin the moment the government was formally sworn in. Immediately following the election, the impact of the Coalition's rhetoric on Australia's relationship with Indonesia was drawn into sharper relief. Abbott's rhetoric began to soften in response, with less focus on Australia's right to protect its borders and more on the benefits that would flow to Indonesia, with whom Abbott pledged to work closely and cooperatively. An interview on the Channel 7 program Sunrise, immediately following the election win, provides a flavour:

David Koch: Mr Abbott, your message to the Indonesians? Coverage of your election was a bit mixed in the media there, and saying the boat policy is just unrealistic.

Tony Abbott: It's in Indonesia's long term best interests for the flow of people to Australia to stop because the vast majority of them come via Indonesia. Many of them stay for many months in Indonesia. While they are in Indonesia, they can be a problem for the Indonesian authorities. I accept that this is a smaller issue for Indonesia than it is for Australia. Indonesia is a vast archipelago with many developmental, economic and social issues. Nevertheless it is going to be good for Indonesia as well as good for Australia that these boats are stopped. (Abbott 2013b) 
In New York, Foreign Minister Bishop met with her Indonesian counterpart during a gathering of the United Nations General Assembly and continued with the softened rhetoric. Bishop described the meeting as 'positive and very productive'. She emphasised the depth of Australia's respect for Indonesia:

There can be some misunderstanding as to what our policy is and it is certainly not to in any way show disrespect for Indonesian sovereignty and for anyone to think that that was our policy that would be a mistake. Our policy respects Indonesia's sovereignty, respects Indonesia's territorial borders, just as Indonesia respects ours. (Connolly 2013)

Indonesian Foreign Minister, Marty Natalegawa, took a different view of proceedings and emphasised that he had passed on a message 'loud and clear' that 'Indonesia cannot accept any Australian policy that would, in nature, violate Indonesia's sovereignty' (Connolly 2013).

The battle for rhetorical consistency came to a head in early October 2013 when Abbott met with Indonesian President Susilo Bambang Yudhoyono in Jakarta. When asked at a post-meeting press conference about his policy for stopping the boats, Abbott's rhetoric focused squarely on the need to work in partnership with Indonesia in every way. He refused to repeat his rhetoric on turning boats around, buying boats in Indonesia or paying Indonesians to provide Australia with information on people smugglers. He fell back on the broader rhetorical point that: 'In the end that is all that really counts - have we stopped the boats?' (Abbott 2013c). Journalists pushed for clearer answers, but Abbott stayed with his higher level rhetoric focused on stopping the boats:

Question: But you are not answering the question will you still turn the boats back to Indonesia?

Prime Minister: Again my object here is to stop the boats. It is to stop the boats and in order to ensure that the boats are stopped I want to have the best possible relationship with Indonesia. We have a great relationship what we are looking to develop is even stronger cooperation on this particular matter in the future than we have always had in the past. (Abbott 2013c)

By being seen to maintain consistency with the broad 'stop the boats' rhetoric, Abbott was able to jettison the sub-parts of that rhetoric without suffering high levels of political pain.

But the tricky balance needed to maintain a unified message whilst delivering different rhetoric to different audiences was highlighted when Morrison, as Immigration Minister, held a press conference in Canberra on 4 October. In an attempt to reassure the domestic Australian audience about the rhetorical 
consistency of the government's position, Morrison insisted that all aspects of the 'stop the boats' policy suite were still available and could be used. 'Despite the wishful thinking and projection by some that I saw in some media reports, there is no change to the Government's policy on border protection. Our resolve, our policies, our commitments to the task remain as strong and are indeed stronger than ever before' (2013). Whilst the press picked up on the rhetorical inconsistency between the message to the two audiences, Abbott's trip was seen as having successfully calmed an issue of dispute between Australia and Indonesia. For example, the softening of rhetoric led to headlines such as 'PM's boats compromise offers a way to ditch tow-back policy' (Bachelard and Wroe 2013).

\section{The importance of rhetorical choices}

The three case studies demonstrate that rhetorical choices matter. They can have enormous consequences for the future political fortunes of political leaders. Particular rhetorical formulations that are successful in entrenching a policy position become ever harder to undo as repetition and recommitment pushes a political actor firmly down a particular path. Each rhetorical act helps to shape not just a policy, but also the public persona of the leader. Any subsequent deviation from a rhetorical path is then seen not just as a change of policy, but as some form of 'betrayal' of a leader's entrenched rhetorical position. Such a betrayal moves the effects of rhetorical path dependency away from simply questions of policy consistency into deeper questions of trustworthiness and authenticity. A change in policy language in one area does not simply result in localised policy pain, but a wider loss of trust in the prime minister and the government they lead.

The fates of both Rudd and Gillard in entrenching a particular policy line, and then attempting a U-turn off that rhetorical path, show just how much rhetorical choices can shape overarching perceptions of a government. Accusations of betraying the electorate and their own principles were so damaging because the change in rhetorical direction reshaped the public persona of both prime ministers in negative ways. Abbott has thus far avoided a similar fate, despite the clear changes in rhetorical emphasis about turning boats back to Indonesia or buying boats in Indonesia. Abbott declined to recommit to either policy despite several invitations to do so during his press conference on the outcomes of his Indonesian visit. It remains to be seen whether this will create similar problems of trust and authenticity in the longer term. In the short term at least, Abbott has been able to maintain the wider rhetorical frame of 'stopping the boats', and shifts in second-tier rhetoric on ways to achieve that broader goal have therefore been less damaging. If Abbott had instead announced in 
Indonesia that changing conditions meant 'stopping the boats' would need to be postponed for three years, the deeper damage to perceptions of his authenticity would have been immense.

So, are political leaders forever stuck with the rhetorical formulations they generate? Can rhetorical path dependency ever be wound back, allowing the clean page to be reset so that a political leader can start again? Tentatively, there do seem to be several options. One means of punctuating this rhetorical path dependence is through an institutionalised action of overriding democratic legitimacy. For example, Howard overcame the stigma of diverting from his promise to 'never ever' again consider a goods and services tax (GST) by taking the policy to an election and being able to claim a democratic mandate for its introduction. In essence, the renewed democratic legitimacy provided by an election was able to wipe clean Howard's rhetorical slate so that he could effectively argue for an alternative policy outcome.

The effects of rhetorical path dependency also appear to be at their strongest only for political leaders rather than backbench members or even ministers. Like the leeway given to teenagers who may stray as they establish the behavioural norms of adult life, politicians are given a chance over time to develop their defining rhetorical refrains and can be forgiven for early inconsistencies. For example, prior to becoming leader of the Liberal Party, Abbott was on the record in support of a market-based mechanism to combat climate change (see Farr 2011). His campaign as Opposition leader against Labor's carbon price/tax and the emissions trading scheme not only contradicted his earlier narrative, but has defined his leadership. Whilst the shift against earlier rhetorical formulations was easily forgiven, as leader it would now be inconceivable for him to argue in favour of a carbon tax without suffering significant political costs. Similarly, as Treasurer in 1985, Paul Keating was an advocate for a consumption tax only to later, as prime minister, win an election by destroying Opposition leader John Hewson's proposal for a consumption tax. It was his rhetoric as leader against a GST that defined his position in a path dependent way. It would then have become inconceivable for him to change again to advocating for a GST without suffering a prohibitive amount of political pain.

Of course, holding an election in order to wipe clean a rhetorical slate is selfevidently not a tool that can be used easily or often. It is full of electoral risk, with Howard himself only just returning to power in 1998 in pursuit of his policy to introduce the GST. Should our political leaders, therefore, simply choose their political rhetoric more carefully, weighing every word lest they make an error or commit to a rhetorical formulation that they will come to regret? There are at least two strong reasons why such an approach would provide little benefit. Firstly, political leaders who weigh their words too carefully risk sounding inauthentic — an ironic outcome considering that speaking rashly 
and then changing your rhetoric down the track has the same result. John Kane and Haig Patapan's (2010) reflections on the 'artless art' of modern rhetoric demonstrate how difficult it is to be both careful and authentic at the same time. Secondly, rhetorical statements that are open and low-risk are unlikely to mount a persuasive case and can leave a leader looking vacuous and unwilling to stand for anything.

As the wide body of literature on the interplay of politics and the media attests, the media plays an important role in framing and entrenching particular rhetorical moments into the wider public imagination (see Weaver 2007, Greenfield and Williams 2003). What the media chooses to focus on can magnify or diminish its impact on the minds of the electorate. Plenty of rhetorical gaffes are made and only mentioned in passing, ensuring that they do not become the basis for an entrenched, path-dependent rhetorical statement. But in many cases, the media are simply responding to what political leaders themselves have sought to emphasise. It was Rudd, not the media, who consistently labelled climate change as a great moral challenge and, in reporting on the subsequent policy about face, the media were simply reflecting on the rhetoric of Rudd's own creation. Similarly with the cases of Gillard and Abbott - each leader emphasised again and again the rhetorical formulation that they wanted to frame their policies within. The fact that the style and content of media reporting, and the desire for 'gotcha' moments, can amplify a rhetorical shift does not diminish the fact that it is political leaders who choose a particular rhetorical path in the first place.

The challenge for political leaders is to be authentic and clear in their rhetorical choices, and accept that this involves a degree of risk that they may be derailed by the difficulties of politics or the complexity of an issue. Representative parliamentary democracy is, after all, a system based on a battle of ideas and competing policies, which cannot hope to be carried out through vague, nondescript rhetorical choices. But equally, leaders must understand the real power that lies in the rhetorical choices they make and the political costs that come from veering from one rhetorical path to another.

\section{References}

Abbott, T. 2013a. A regional deterrence framework to combat people smuggling. Liberal Party of Australia. 23 August. URL: http://www.liberal.org.au/latestnews/2013/08/23/tony-abbott-regional-deterrence-framework-combatpeople-smuggling. Consulted 4 October 2013. 
2013b. Interview with David Koch and Samantha Armytage. Sunrise. Liberal Party of Australia. 10 September. URL: http:/www.liberal.org.au/ latest-news/2013/09/10/tony-abbott-interview-david-koch-and-samanthaarmytage-sunrise. Consulted 4 October 2013.

2013c. Joint press conference with Minister Julie Bishop, Jakarta. Prime Minister of Australia. 1 October. URL: http://www.pm.gov.au/ media/2013-10-01/joint-press-conference-minister-julie-bishop-jakarta. Consulted 17 October 2013.

Australian Broadcasting Corporation (ABC) 2010. Abbott under fire for 'gospel truth' gaffe. ABC News 18 May. URL http://www.abc.net.au/news/2010-05-18/ abbott-under-fire-for-gospel-truth-gaffe/830636. Consulted 14 October 2013.

Australian Financial Review (AFR). 2010. Seeking 'community consensus' ahead of an ETS. 28 June. URL: http://www.afr.com/p/national/seeking community_consensus_ahead_DoPyom16hbN8c6by6fsaaJ. Consulted 25 September 2013.

Bachelard, M. and Wroe, D. 2013. PM's boats compromise offers a way to ditch tow-back policy.Sydney Morning Herald 2 October. URL: http://www.smh. com.au/federal-politics/political-news/pms-boats-compromise-offers-a-wayto-ditch-towback-policy-20131001-2uqs1.html. Consulted 4 October 2013.

Connolly, E. 2013. Indonesia voices concerns about Coalition's boats policy 'loud and clear'. Canberra Times 25 September. URL: http://www.canberratimes. com.au/federal-politics/political-news/indonesia-voices-concerns-aboutcoalitions-boats-policy-loud-and-clear-20130925-2ucuz.html?skin=textonly. Consulted 11 October 2013.

Farr, M. 2011. Opposition leader Tony Abbott changes line, says he never supported ETS. Daily Telegraph 20 July. URL: http://www.dailytelegraph.com. $\mathrm{au} /$ news/national/opposition-leader-tony-abbott-changes-line-says-he-neversupported-ets/story-e6freuzr-1226098237952. Consulted 17 October 2013.

Gains, F., John, P.C. and Stoker, G. 2005. Path dependency and the reform of English local government. Public Administration 83(1): 25-45.

Gillard, J. 2010a. Transcript of interview with Laurie Oakes, Weekend today 27 June. URL: http://parlinfo.aph.gov.au/parlInfo/search/display/display.w3p; $\mathrm{adv}=$ yes;orderBy=customrank;page $=1$; query $=$ Gillard $\% 20 \% 22$ Climate $\% 20$ change \% 22\%20Date \%3 A $26 \% 2$ F06\%2F $2010 \% 20 \% 3$ E \% 3E\% 20 $27 \% 2 \mathrm{~F} 06 \% 2 \mathrm{~F} 2010 \% 20 \mathrm{Dataset} \% 3 \mathrm{Apressrel}$,pressclp,emms,radioprm,tvpro g, broadcastOther;rec=14;resCount=Default. Consulted 25 September 2013. 
2010b. Transcript of interview on Ten News. 16 August. URL: http:// parlinfo.aph.gov.au/parlInfo/search/display/display.w3p;adv=yes;orderB $\mathrm{y}=$ customrank; page $=0$; query $=$ Ten $\% 20$ Date $\% 3 \mathrm{Al} \% 2 \mathrm{~F} 08 \% 2 \mathrm{~F} 2010 \% 20$ $\% 3 \mathrm{E} \% 3 \mathrm{E} \% 2017 \% 2 \mathrm{~F} 08 \% 2 \mathrm{~F} 2010 \% 20$ Dataset $\% 3 \mathrm{Aemms}$,radioprm,tvprog, broadcastOther;rec $=1 ;$ resCount $=$ Default. Consulted 11 October 2013.

2011. Transcript of joint press conference, Canberra. 24 February. URL: http://parlinfo.aph.gov.au/parlInfo/search/display/display.w3p;adv=yes; orde rBy $=$ customrank; page $=0$; query $=$ Gillard $\% 20 \% 22$ carbon $\% 20$ price $\% 22 \% 20$ Date \%3A20\%2F02\%2F2011\%20\%3E\%3E\%2028\%2F02\%2F2011\%20 Dataset \%3Apressrel;rec=12;resCount=Default. Consulted 25 September 2013.

2013. Julia Gillard writes on power, purpose and Labor's future. Guardian 14 September. URL: http://www.theguardian.com/world/2013/sep/13/juliagillard-labor-purpose-future. Consulted 25 September 2013.

Greenfield, C. and Williams, P. 2003. Limiting politics: Howardism, media rhetoric and national cultural commemorations. Australian Journal of Political Science 38(2): 279-97.

Hall, B. 2013. Coalition defies Indonesia with boat tow-back policy. Sydney Morning Herald 8 July. URL: http://www.smh.com.au/federal-politics/ federal-election-2013/coalition-defies-indonesia-with-boat-towback-policy20130707-2pkb2.html. Consulted 4 October 2013.

Hartcher, P. 2010. How Abbott found an unexpected ally over climate change in the Gang of Four. Sydney Morning Herald 26 June. URL: http://www. smh.com.au/federal-politics/political-opinion/how-abbott-found-anunexpected-ally-over-climate-change-in-the-gang-of-four-20100625-z9r6. html. Consulted 25 July 2013.

Howard, J. 2001. John Howard's 2001 election campaign policy launch speech. 28 October. Immigration Museum. URL: http://museumvictoria.com.au/ immigrationmuseum/discoverycentre/identity/videos/politics-videos/johnhowards-2001-election-campaign-policy-launch-speech/. Consulted 16 October 2013.

Kane, J. and Patapan, H. 2010. The artless art: Leadership and the limits of democratic rhetoric. The Australian Journal of Political Science 45(3): 371-89.

Kelly, P. 2010. Rudd's dangerous climate retreat. Australian 28 April. URL: http://www.theaustralian.com.au/opinion/rudds-dangerous-climate-retreat/ story-e6frg6zo-1225859076778. Consulted 24 September 2013. 
2012. I'll turn back every boat, says Tony Abbott. Australian 21 January. URL: http://www.theaustralian.com.au/national-affairs/ill-turn-back-everyboat-says-tony-abbott/story-fn59niix-1226249863706\#. Consulted 4 October 2013.

Maiden, S. 2010. Gillard says she led push for delay on ETS. Australian 28 June. URL: http://www.theaustralian.com.au/news/gillard-says-she-led-push-fordelay-on-ets/story-e6frg6n6-1225884955922. Consulted 25 September 2013.

Morrison, S. 2013. Minister for Immigration and Border Protection and Acting Commander of Operation Sovereign Borders Joint Agency Task Force address press conference on Operation Sovereign Borders. Australian Customs and Border Protection Service. 4 October. URL: http://www.customs.gov. au/site/131004transcript_operation-sovereign-borders.asp. Consulted 17 October 2013.

Peake, R. 2012. No turning back on Abbott navy stance. Canberra Times 12 July. URL: http://www.canberratimes.com.au/national/no-turning-back-onabbott-navy-stance-20120711-21wld.html. Consulted 4 October 2013.

Pierson, P. 2000. Increasing returns, path dependence, and the study of politics. American Political Science Review 94(2): 251-67.

Rudd, K. 2006. Faith in politics. The Monthly October 2006. URL: http://www. themonthly.com.au/issue/2006/october/1330040298/kevin-rudd/faithpolitics. Consulted 11 October 2013.

2008. Joint press conference with Minister Penny Wong and Premier Mike Rann, Lower Lakes, Murray Darling, South Australia. Prime Minister of Australia. 5 July. URL: http://pandora.nla.gov.au/pan/79983/200811120133/www.pm.gov.au/media/Interview/2008/interview_0348.html. Consulted 24 September 2013.

2010. Transcript of doorstop. Nepean Hospital, Penrith. Prime Minister of Australia. 27 April. URL: http://pandora.nla.gov.au/pan/79983/201006241429/www.pm.gov.au/node/6708.html. Consulted 24 September 2013.

Sydney Morning Herald 2010. Gillard rules out imposing carbon tax. 17 August. URL: http://m.smh.com.au/federal-election/climate/gillard-rules-out-imposingcarbon-tax-20100816-1270b.html. Consulted 25 September 2013.

Taylor, L. 2010. Decision to put climate action on hold smacks of political cowardice.Sydney Morning Herald 28 April. URL: http://www.smh.com.au/ federal-politics/political-opinion/decision-to-put-climate-action-on-holdsmacks-of-political-cowardice-20100427-tqlh.html. Consulted 17 October 2013. 
Weaver, D. 2007. Thoughts on agenda setting, framing, and priming. Journal of Communication 57(1): 142-47.

Wilson, L. and Vasek, L. 2012. I will still turn boats around, Tony Abbott says. Australian7 July.URL:http://www.theaustralian.com.au/national-affairs/i-willstill-turn-boats-around-tony-abbott-says/story-fn59niix-1226419434930\#. Consulted 4 October 2013.

Wroe, D. and Hall, B. 2013. Say we vote to turn back those boats. What next? Sydney Morning Herald 13 July. URL: http://www.smh.com.au/federalpolitics/federal-election-2013/say-we-vote-to-turn-back-those-boats-whatnext-20130712-2pvkg.html. Consulted 17 October 2013. 
This text taken from Studies in Australian Political Rhetoric, Edited by John Uhr and Ryan Walter, published 2014 by ANU Press, The Australian National University, Canberra, Australia. 